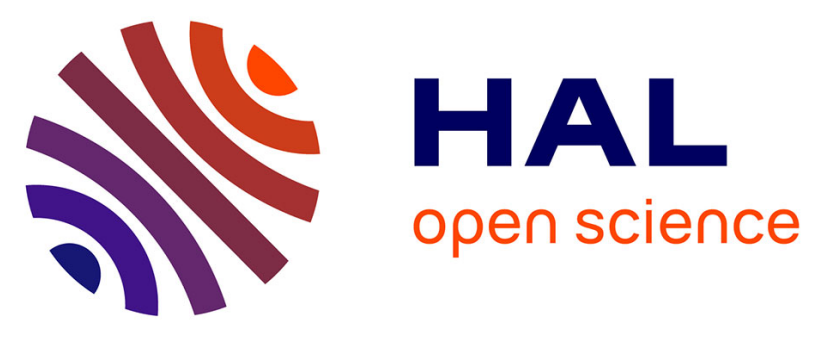

\title{
Pharmacological Properties of 5-Hydroxytryptamine4 Receptor Antagonists on Constitutively Active Wild-Type and Mutated Receptors
}

Sylvie Claeysen, Michèle Sebben, Carine Becamel, Richard M Eglen, Robin D Clark, Joël Bockaert, Aline Dumuis

\section{To cite this version:}

Sylvie Claeysen, Michèle Sebben, Carine Becamel, Richard M Eglen, Robin D Clark, et al.. Pharmacological Properties of 5-Hydroxytryptamine4 Receptor Antagonists on Constitutively Active Wild-Type and Mutated Receptors. Molecular Pharmacology, 2000, 58 (1), pp.136-144. 10.1124/mol.58.1.136 . hal-02487689

\section{HAL Id: hal-02487689 \\ https://hal.science/hal-02487689}

Submitted on 21 Feb 2020

HAL is a multi-disciplinary open access archive for the deposit and dissemination of scientific research documents, whether they are published or not. The documents may come from teaching and research institutions in France or abroad, or from public or private research centers.
L'archive ouverte pluridisciplinaire HAL, est destinée au dépôt et à la diffusion de documents scientifiques de niveau recherche, publiés ou non, émanant des établissements d'enseignement et de recherche français ou étrangers, des laboratoires publics ou privés. 


\section{Pharmacological Properties of 5-Hydroxytryptamine 4 Receptor Antagonists on Constitutively Active Wild-Type and Mutated Receptors}

Sylvie Claeysen ${ }^{1}$, Michèle Sebben ${ }^{1}$, Carine Bécamel ${ }^{1}$, Richard M. Eglen ${ }^{2}$, Robin

D. Clark ${ }^{2}$, Joël Bockaert ${ }^{1, *}$ and Aline Dumuis ${ }^{1}$

${ }^{1}$ CNRS UPR 9023, Centre CNRS-INSERM de Pharmacologie-Endocrinologie (CCIPE), 141 rue de la Cardonille, 34094 Montpellier cedex 5,France

${ }^{2}$ Center for Biological Research, Neurobiology Unit, Roche Bioscience, 3401 Hillview Ave R2-101, PALO ALTO, CA 94304-1397, USA

*Corresponding author:

Joël BOCKAERT, CNRS UPR 9023, Centre CNRS-INSERM de PharmacologieEndocrinologie (CCIPE), 141 rue de la Cardonille, 34094 Montpellier cedex 5, France

Phone: (33) 04 67-14-29-30 ; Fax: (33) 04 67-54-24-32

Email: bockaert@ccipe.montp.inserm.fr

Running title: $5-\mathrm{HT}_{4}$ receptor antagonists and constitutive activity

Abbreviations: GPCRs, G-protein coupled receptors; 5-HT4R, 5-Hydroxytryptamine 4 receptor; RT-PCR, reverse transcriptase polymerase chain reaction; dFBS, dialyzed fetal bovine serum; $\mathrm{R}$, inactive receptor conformation; $\mathrm{R}^{*}$, active receptor conformation.

This work was supported by grants from the Fondation pour la Recherche Médicale and Roche Bioscience. 


\begin{abstract}
We studied the pharmacological properties of twenty-four 5-hydroxytryptamine $(5-\mathrm{HT})_{4}$ receptor ligands known to act as antagonists on $5-\mathrm{HT}_{4}$ receptors positively coupled to adenylyl cyclase endogenously expressed in mouse colliculi neurons. In COS-7 cells expressing human or mouse 5-HT4(a) receptors (100-8000 fmol/mg of protein), we found neutral antagonists, partial agonists, and inverse agonists. The majority of neutral antagonists belong to the benzodioxanyl ketone class, whereas partial agonists belong to different chemical classes. We found only two inverse agonists, GR 125487 and SB 207266, which are both indoles. Analysis of pharmacological characteristics of the constitutively active wildtype and constitutively active mutated receptors revealed that 1) the ratio between the efficiencies of the full agonist 5-HT and the partial agonist RS 23597 was invariable when the receptor density increased, but was dependent on receptor structure; 2) similarly, the efficacy of the inverse agonist SB 207266 was not dependent on receptor density but was dependent on receptor structure; 3) when the receptor concentration increased, the $\mathrm{EC}_{50}$ values of the full agonist 5-HT were not modified and the increase in basal constitutive activity, as well as its stimulation by 5-HT, followed a parallel evolution; and 4) the stimulation of basal constitutive activity by 5 -HT was not modified by the overexpression of Gas. All these results indicate that in COS-7 cells, the coupling of the 5- $\mathrm{HT}_{4}$ receptor to adenylyl cyclase was linear with no indication of spare receptors even at high receptor density $(8 \mathrm{pmol} / \mathrm{mg})$. These results are also in accordance with a precoupling between the activated receptor $\left(f_{\mathrm{R}^{*}}\right)$ and adenylyl cyclase. Such observations allowed us to use the twostate model to calculate the constant J, i.e., the equilibrium allosteric constant denoting the ratio of the receptor in the inactive versus active state $\left(J=[R] /\left[R^{*}\right]\right)$. We found that $J$ was a receptor structural characteristic, independent of receptor density.
\end{abstract}




\section{INTRODUCTION}

Until recently, classical theories of G protein-coupled receptors (GPCRs) activation assumed that agonist binding by receptors led to a change in conformation. This change was supposed to provide a way for the receptor-agonist complex to activate the $G$ proteins. Recent descriptions of basal constitutive activity of GPCRs and inverse agonism have shed light on several new issues (Costa et al., 1992; Kjelsberg et al., 1992; Samama et al., 1993; Bond et al., 1995). One issue concerns the behavior of receptor antagonists; the other concerns the nature of basal constitutive activity. It is now evident that compounds that were considered to be antagonists indeed behave as partial agonists, neutral antagonists, or inverse agonists when tested on constitutively active receptors (Chidiac et al., 1994). There are limited data reporting the possible "physiological" role of basal constitutive activity of GPCRs. One study concerns opsin, the rhodopsin apoprotein. The constitutive activity of opsin is certainly responsible for transduction noise caused by previous light exposure (Surya et al., 1995). If such noise exists in other GPCR systems, it is important to determine the pharmacological characteristics of antagonists, especially those used in clinical tests because a neutral antagonist may not have the same therapeutic effect as an inverse agonist.

The primary goal of this study was to determine the efficacy of classical 5hydroxytryptamine $(5-\mathrm{HT})_{4}$ receptor antagonists on $5-\mathrm{HT}_{4}$ receptors transfected in COS-7 cells. 5- $\mathrm{HT}_{4}$ receptors are Gs-coupled GPCRs showing marked constitutive activity at low physiologically relevant concentrations when transfected in different cell lines (Claeysen et al., 1997, 1999).

The secondary goal was to analyze the pharmacological properties of constitutively active wild-type and mutated 5-HT4receptors. Specifically, receptor reserve was studied. In COS-7 cells, we found that native or mutated $5-\mathrm{HT}_{4}$ receptors could be expressed without showing any significant receptor reserve. Finally, we took advantage of this cellular preparation, in which the relationship between receptor density and cAMP production was quasi-linear, to analyze our results with the two-state allosteric model. This model was introduced by Monod et al. (1965) and developed by Karlin (1967), Thron (1970), Colquhoun (1973), and Leff (1995) in the context of GPCRs. It has been used by Bond et al. (1995) to describe the physiological effects of inverse agonists in transgenic mice with myocardial overexpression of the $\beta_{2}$-adrenoreceptor. Making some minimal assumptions, we calculated the J constant, the allosteric equilibrium constant denoting the ratio between the inactive $(\mathrm{R})$ and the active $\left(\mathrm{R}^{*}\right)$ states of the receptor, $\mathrm{J}=[\mathrm{R}] /\left[\mathrm{R}^{*}\right]$, which to date has never been determined experimentally. As expected from the two-state model, we found that $\mathbf{J}$ was independent of the receptor density but dependent on receptor structure. 


\section{MATERIALS AND METHODS}

\section{Cell culture and transfection.}

cDNA, subcloned into pRK5, was introduced into COS-7 cells by electroporation as described in Claeysen et al. (1996). Briefly, cells were trypsinized, centrifuged, and resuspended in electroporated buffer $\left(50 \mathrm{mM} \mathrm{K}_{2} \mathrm{HPO}_{4}, 20 \mathrm{mM} \mathrm{CH} \mathrm{CO}_{2} \mathrm{~K}, 20 \mathrm{mM} \mathrm{KOH}\right.$, $26.7 \mathrm{mM} \mathrm{MgSO}_{4}, \mathrm{pH} 7.4$ ) with 25 to $2000 \mathrm{ng}$ of receptor cDNA. The total amount of DNA was kept constant at $15 \mu \mathrm{g} /$ transfection with wild-type pRK5 vector. After $15 \mathrm{~min}$ at room temperature (RT), $300 \mu \mathrm{l}$ of cell suspension $\left(10^{7} \mathrm{cells}\right)$ was transferred to a $0.4-\mathrm{cm}$ electroporation cuvette (Bio-Rad, Heidemannstrabe, Munchem) and pulsed with a Gene pulser apparatus (setting $1000 \mu \mathrm{f}, 280 \mathrm{~V}$ ). Cells were diluted in Dulbecco's modified Eagle's medium (DMEM; $10^{6}$ cells $/ \mathrm{ml}$ ) containing 10\% dialyzed fetal bovine serum (dFBS) and plated on 15-cm Falcon Petri dishes or into 12-well clusters at the desired density.

\section{Determination of cAMP production in intact cells.}

Six hours after transfection, cells were incubated overnight in DMEM without dialyzed fetal bovine serum (dFBS) with $2 \mu \mathrm{Ci}\left[{ }^{3} \mathrm{H}\right]$-adenine $/ \mathrm{ml}$ to label the ATP pool and cAMP accumulation was measured as described in Dumuis et al. (1988).

\section{Membrane preparations and radioligand binding assay.}

Membranes were prepared from transiently transfected cells plated on $15-\mathrm{cm}$ dishes and grown in DMEM with 10\% dFBS for $6 \mathrm{~h}$ and $20 \mathrm{~h}$ in DMEM without dFBS as previously described (Ansanay et al., 1996). The cells were washed twice in PBS, scraped with a rubber policeman, harvested in PBS, and centrifuged at $4^{\circ} \mathrm{C}(200 \mathrm{~g}$ for $4 \mathrm{~min})$. The pellet was resuspended in buffer containing $10 \mathrm{mM}$ HEPES (pH 7.4), 5 mM EGTA, 1 mM EDTA, and $0.32 \mathrm{M}$ sucrose, and homogenized 10 times with a glass-Teflon potter at $4^{\circ} \mathrm{C}$. The homogenate was centrifuged at $20,000 \mathrm{~g}$ for $20 \mathrm{~min}$, and the membrane pellet was resuspended in $50 \mathrm{mM}$ HEPES (pH 7.4; $5 \mathrm{mg}$ of protein in $1 \mathrm{ml}$ of solution) and stored at $-80^{\circ} \mathrm{C}$ until use.

$5-\mathrm{HT}_{4}$ receptor densities were estimated with the specific radioligand $\left[{ }^{3} \mathrm{H}\right] \mathrm{GR} 113808$ at saturating concentration $\left(0.4-0.6 \mathrm{nM}, K_{\mathrm{d}}=0.12 \mathrm{nM}\right)$ as described previously. 5-HT $(50 \mu \mathrm{M})$ was used to determine nonspecific binding. Protein concentration in the samples was determined with the Bio-Rad protein assay (Bradford, 1976). 


\section{Membrane preparation, gel electrophoresis, and immunoblotting.}

$\mathrm{G} \alpha_{\mathrm{s}}$ cDNA subcloned into pRK5 was transfected in COS-7 cells. Membranes were prepared from cells plated on 10-cm dishes, washed twice in PBS, scraped with a rubber policeman, harvested in PBS, and centrifuged at $4^{\circ} \mathrm{C}$ (200gfor $\left.4 \mathrm{~min}\right)$. The pellet was resuspended in a lysis buffer containing $50 \mathrm{mM}$ Tris ( $\mathrm{pH}$ 7.4), $1 \mathrm{mM}$ EDTA, and protease inhibitors then homogenized 20 times with a glass-Teflon potter at $4^{\circ} \mathrm{C}$. The homogenate was centrifuged at $100,000 \mathrm{~g}$ for $1 \mathrm{~h}$, and the membrane pellet was resuspended in a lysis buffer and sonicated for $20 \mathrm{~s}$. A Laemmli sample buffer was then added.

Membrane extract $(30 \mu \mathrm{g})$ was loaded per lane and electrophoresed on 12\% SDSpolyacrylamide gel electrophoresis gels. Proteins were transferred onto nitrocellulose (Amersham Pharmacia Biotech, Little Chalfont, UK) by humid transfer and the membranes

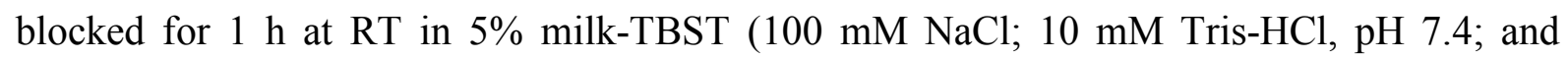
$0.05 \%$ Tween 20). The membranes were incubated overnight at $4{ }^{\circ} \mathrm{C}$ with Gas-specific antibodies produced by Dufour M-N (Centre National de la Recherche Scientifique Unité Propre de Recherche, Montpellier, France). The antibodies were generated in rabbits against a synthetic peptide RMHLRQYELL, corresponding to the C-terminal region of all the forms of the $\alpha$-subunit of Gs: Gas (short; $45 \mathrm{kDa}$ ) and Gas (long; $52 \mathrm{kDa}$ ). The antibodies were used at a dilution of 1:500 onto blocking buffer. After extensive washing in TBST, membranes were incubated for at least $1 \mathrm{~h}$ at RT with peroxidase-coupled secondary antiserum, diluted in 5\% milk-TBST (1:4000 for anti-rabbit). After further washing, the immunocomplexes were revealed by enhanced chemiluminescence (Renaissance Plus; NEN Life Science Products, Zaventem, Belgium).

\section{Data analysis}

The dose-response curves were fitted according to the equation $y=\left(\left(y_{\max }-y_{\min }\right) / 1+(\mathrm{x} /\right.$ $\left.\mathrm{EC} 50) n_{\mathrm{H}}+y_{\mathrm{min}}\right)$ where $\mathrm{EC}_{50}$ is the concentration of agonist giving a response equal to $50 \%$ of the maximum, $y_{\max }$ and $y_{\min }$ correspond to the maximal and minimal values, and $n_{\mathrm{H}}$ is the Hill coefficient, using the Kaleidagraph program. Statistical differences were examined with the Stat-View Student program (Abacus Concepts, Berkeley, CA) with $t$ tests.

\section{Drugs.}

GR 113808 ([1-[2(methylsulphonyl-amino)ethyl]4-piperidinyl]methyl-1-methyl-indole-3 carboxylate, maleate) and GR 125487 ([1-[2(methylsulphonyl-amino)ethyl]4piperidinyl]methyl-5-fluoro-2-methoxy-1-H-indole-3-carboxylate, hydrochloride) were 
synthesized and generously donated by Glaxo (Ware, UK). $\left[{ }^{3} \mathbf{H}\right]$ GR 113808 was purchased from Amersham and 5-HT was purchased from Sigma Chemical Co., St. Louis, MO. SB 204070 [(1-n-butyl-4-piperidinyl)methyl-8-amino-7-chloro-1,4-benzodioxane-5-carboxylate] was synthesized and generously donated by SmithKline Beecham Pharmaceuticals (New Frontiers Science Park, Halow, Essex, UK). LY 353433 \{1-(1-methylethyl)- $N$-[2-[4[[(tricyclo[3.3.1.1.]dec-1-ylcarbonyl)amino]-piperidinyl]ethyl]-1 $H$-indazole-3-carboxamide) $\}$ and SB $207266\{(N-1-$ butyl-4-piperinylmethyl)-3,4-dihydro-2 $H$-[1,3] oxazino[3,2- $a$ ]indole10-carboxamide, hydrochloride $\}$ were obtained from Laboratoires Fournier-Debat (Daix, France). ML 10302 [2-(1-piperidinyl)ethyl 4-amino-5-chloro-2-methoxybenzoate] and ML 10375 [2-(cis-3,5-dimethylpiperidino) ethyl 4-amino-5-chloro-2 methoxybenzoate] were synthesized and obtained from M. Langlois, Centre National de la Recherche ScientifiqueBIOCIS, Châtenay-Malabry, France. DAU 6285 \{(endo-6-methoxy-8-methyl-8-azabicyclo [3.2.1] oct 3-yl)-2,3-dihydro-2-oxo-1H-benzimidazole-1 carboxylate hydrochloride\} was obtained from Boehringer Ingelheim, Milan, Italy; SDZ 205557 [2-methoxy-4-amino-5chlorobenzoic acid 2-(diethylamino) ethyl ester, hydrochloride] and Tropisetron (ICS 205 930; [(3a tropanyl)- $1 H$-indole-3-carboxylic acid ester] were obtained from Sandoz Pharma, Basel, Switzerland; and RS 23597 [3-(piperidine-1-yl) propyl-4-amino-5-chloro-2-methoxybenzoate hydrochloride], RS 39604 [1-[4-amino-5-chloro-2-(3,5-dimethoxybenzyloxy)phenyl]-3-[1-[2-[(methylsulfonyl)amino] ethyl]]-4-piperidinyl]]-1-propanone hydrochoride, $\quad$ RS $\mathbf{1 0 0 2 3 5}\{1$-(8-amino-7-chloro-1,4-benzodioxan-5-yl)-3-[[3,4dimethoxyphenyl)prop-1-yl]piperidin-4-yl]propan-1-one $\}$, RS $057261\{1$-(8-amino-7-chloro2,3-dihydro-benzo[1,4]dioxin-5-yl)-3-(1-[3-(4-methoxy-phenyl)-propyl]-piperidin-4-yl)propan-1-one $\}, \mathbf{R S} \mathbf{1 0 0 3 0 3}\{N$-(2-(4-[3-(8-amino-7-chloro-2,3-dihydro-benzo[1,4]dioxin-5yl)-3-oxo-propyl]-piperidin-1-yl)-ethyl1)-ethyl)-benzenesulfonamide $\}, \mathbf{R S} 100350\{N-(2(4-$ [3-(8-amino-7-chloro-2,3-dihydro-benzo[1,4]dioxin-5-yl)-3-oxo-propyl]-piperidin-1-yl)ethyl1)-4-methoxy-benzenesulfonamide $\}, \quad$ RS $124478\{N-(3$ (4-[3-(8-amino-7-chloro-2,3dihydro-benzo[1,4]dioxin-5-yl)-3-oxo-propyl]-piperidin-1-yl)-propyl) methanesulfonamide , RS $124523\{1$-(8-amino-7-chloro-2,3-dihydro-benzo[1,4]dioxin-5-yl)-3-(1-[3-(4-fluorophenyl)-propyl]-piperidin-4-yl)-propan-1-one $\}, \quad$ RS $124548 \quad\{1$-(8-amino-7-chloro-2,3dihydro-benzo[1,4]dioxin-5-yl)-3-[1-(3-ethoxy-propyl]-piperidin-4-yl)-propan-1-one\}, $\quad$ RS $47109\{1$-(8-amino-7-chloro-2,3-dihydro-benzo[1,4]dioxin-5-yl)-3-(1-butyl-piperidin-4-yl)propan-1-one $\}, \quad$ RS $67532\{1$-(8-amino-5-chloro-2-(3,5-dimethoxy-benzyloxy)-phenyl]-5piperidin-1-yl)-pentan-1-one\}, RS 47431 \{1-(4-amino-5-chloro-2-methoxy-phenyl]-3-(1-[3(4-methoxy-phenyl)-propyl]-piperidin-4-yl)-propan-1-one\}, RS 79842 44-amino-5-chloro-2methoxy- $N$-(1-[3-(4-methoxy-phenyl)-propyl]-piperidin-4-ylmethyl)-benzamide\}, and RS 
54580 \{1-(4-amino-5-chloro-2-methoxy-phenyl]-3-(1-[3-(4-dimethoxy-phenyl)-propyl]piperidin-4-yl)-propan-1-one\} were synthesized and generously donated by Roche Bioscience, Palo Alto, CA.

\section{RESULTS}

Effects of a series of $5-\mathrm{HT}_{4}$ receptor antagonists on agonist-independent camp production in COS-7 cells expressing transiently either human or mouse 5-HT $4($ a) receptors

As previously reported (Claeysen et al., 1999), COS-7 cells expressing 200 to $500 \mathrm{fmol} / \mathrm{mg}$ of receptor protein exhibited, in the absence of agonist, cAMP production (constitutive activity) that was 2- to 4-fold higher than that measured in mocked transfected cells (true basal activity; Fig. 1). We first studied the potential neutral antagonist, partial agonist, and inverse agonist properties of a series of drugs that behave as $5-\mathrm{HT}_{4}$ neutral antagonists in colliculi neurons, one of the most studied 5-HT4 receptor-expressing cells (Dumuis et al., 1988; Bockaert et al., 1997; Clark, 1998; our unpublished data). Three main chemical classes of antagonists acting on both human and mouse 5 - $\mathrm{HT}_{4(\mathrm{a})}$ receptors were analyzed (Bockaert et al., 1997). The compounds acting as neutral antagonists generally came from the benzodioxanyl ketone class (Fig. 1 , A and D). There were two exceptions, the benzoate ML 10375 and the indole GR 113808. The 5-HT 4 receptor ligands that displayed partial agonistic properties belonged to several chemical classes (Fig. 1, B and E): benzoates (SDZ 205557); benzamides (RS 79842); aryl ketones (RS 67532, RS 39604, RS 47431); indazole amide (LY 353433, SB 204070, RS 54580); indole carboxylate (tropisetron); and benzimidazolones (DAU 6285). The efficiencies of all these compounds, relative to that of 5-HT, varied from $18 \pm 4$ to $64 \pm 5 \%$ (Fig. $1, \mathrm{~B}$ and $\mathrm{E}$ ). We found only two potent 5 - $\mathrm{HT}_{4}$ receptor ligands behaving as inverse agonists, an indole carboxylate (GR 125487) and an indole amide (SB 207266; Fig. 1, C and F).

Concentration-response curves of five $5-\mathrm{HT}_{4}$ receptor antagonists on agonistindependent and -dependent camp production in COS-7 cells transiently expressing m5-HT $_{4(\mathbf{a})}$ receptors.

As expected, partial agonists were able to inhibit the 5-HT-stimulated cAMP production to 
levels corresponding to the cAMP productions observed when they were applied alone at maximal concentrations (Fig. 2, A and B). Note that there was no relationship between potencies and efficiencies of these compounds.

Concentration-response curves of two potent and selective inverse agonists, GR 125487 and SB 207266, on agonist-independent and -dependent camp production on COS-7 cells transiently expressing $\mathrm{m}^{-}-\mathrm{HT}_{4(\mathrm{a})}$ receptors

The two compounds acting as inverse agonists (Fig. 1, C and F), dose dependently inhibited basal constitutive activity (Fig. 3, A and B). GR 125487 was 6- to 10 -fold more potent than SB 207266. In contrast, SB 207266 was more efficacious than GR 125487. They reduced the basal constitutive activities to $22 \pm 7$ and $35 \pm 5 \%$, respectively. Both drugs also were able to inhibit the 5-HT responses. As expected, at high inverse agonist concentrations, cAMP productions were similar to those measured in the absence of 5-HT. Again, GR 125487 was more potent than SB 207266.

\section{Absence of effect of receptor density on partial agonist RS 23597 and inverse agonist SB 207266 efficiencies}

When the density of $5-\mathrm{HT}_{4(\mathrm{a})}$ receptors was increased from 200 to $8300 \mathrm{fmol} / \mathrm{mg}$ of protein, we observed an increase in basal constitutive activity, as well as a proportional increase in the 5-HT-stimulated response (Fig. 4A). However, in contrast to what was expected if spare receptors were present (Leff, 1988; Kenakin and Morgan, 1989), we found that the efficacy of the partial agonist RS 23597 relative to that of 5-HT was constant regardless of receptor density (Fig. 4C). Similar results were observed when constitutively active, mutated 5-HT 4 receptors (5-HT $\mathrm{H}_{4} \mathrm{RA} 258 \mathrm{~L}$ and $5-\mathrm{HT}_{4} \mathrm{R} \Delta 327$; Claeysen et al., 1999) were studied. The efficacy of RS 23597 was characteristic of the receptor $(45 \pm 3,69 \pm 5$, and $83 \pm 7 \%$ for wild-type 5$\mathrm{HT}_{4(\mathrm{a})} \mathrm{R}, 5-\mathrm{HT}_{4} \mathrm{R} \Delta 327$, and the 5-HT4RA258L, respectively; Fig. 4E).

Although the efficacy of partial agonists has been measured in many cellular systems, particularly as a function of receptor density, no such data are available for inverse agonists. The efficacy of SB 207266 in inhibiting activity of the wild-type 5-HT4R, as well as the constitutively active, mutated $5-\mathrm{HT}_{4} \mathrm{R}\left(5-\mathrm{HT}_{4} \mathrm{RA} 258 \mathrm{~L}\right.$ and $\left.5-\mathrm{HT}_{4} \mathrm{R} \Delta 327\right)$, was constant regardless of receptor density (Fig. 4D and F). The efficacy of the inverse agonist was $70 \pm 3$, $50 \pm 4$, and $32 \pm 3 \%$ for wild-type $5-\mathrm{HT}_{4(\mathrm{a})} \mathrm{R}, 5-\mathrm{HT}_{4} \mathrm{R} \Delta 327$, and $5-\mathrm{HT}_{4} \mathrm{RA} 258 \mathrm{~L}$, respectively. Together, these observations clearly indicate that the efficacy of the inverse agonist was a characteristic of receptor structure. 


\section{Absence of effect of receptor density on 5-HT response curves}

We determined whether the cellular model used herein expressed receptor reserve and a nonlinear behavior as a function of receptor density. As seen in Fig. 5, A and B, the stimulation of the basal constitutive activity by 5-HT was constant regardless of receptor density (up to $8000 \mathrm{fmol} / \mathrm{mg}$ of protein). In addition, the $\mathrm{EC}_{50}$ of the dose-response curves did not shift to the left (Fig. $\underline{5}$ C). Similarly, the 5-HT stimulation of basal constitutive activity was constant regardless of the concentration of mutated receptors $\left(5-\mathrm{HT}_{4} \mathrm{RA} 258 \mathrm{~L}\right.$ and $5-\mathrm{HT}_{4} \mathrm{R} \Delta 327$; Fig. $\left.5 \mathrm{D}\right)$. However, the 5-HT stimulation of basal constitutive activity was a receptor characteristic (Fig. $\underline{5} \mathrm{D}$ ). It was lower for mutated than for wild-type 5-HT ${ }_{4} \mathrm{R}$. Note that we have previously found that the mutated receptors yielded higher basal constitutive activities than the wild-type 5-HT 4 R (Claeysen et al., 1999 and legends to Figs. 4 and 5).

\section{Concentrations of Gs and adenylyl cyclase did not limit 5-HT-stimulated cAMP production regardless of receptor density}

One important parameter to consider when analyzing receptor efficacy is whether there is a limiting factor between activated receptors and the measured function. In this study, the measured function is cAMP production. As seen in Fig.6, 5-HT stimulation of basal activity did not significantly change regardless of receptor density when we overexpressed $\mathrm{G} \alpha_{\mathrm{s}}$. This suggests that neither $\mathrm{G} \alpha_{\mathrm{s}}$ nor adenylyl cyclase were limiting.

Determination of the allosteric equilibrium constant $J$ denoting ratio between inactive $R$ and active $R *$ state of $5-H_{4}$ receptors according to two-state model.

Three main models have been used to explain results obtained with GPCRs that exhibit constitutive activities and on which some ligands are inverse agonists: the two statemodel(Bond et al., 1995; Leff, 1995), the extended ternary complex model (Samama et al., 1993), and the cubic ternary complex model (Kenakin, 1996). We analyzed our results with the simplest one, the two-state model. This model can be represented as shown in Scheme 1 The receptor exists in two forms, $\mathrm{R}$ and $\mathrm{R}^{*}$. In the absence of a ligand (L), the distribution between the two states is governed by the equilibrium constant

\section{$J=[R] /\left[R^{*}\right] \quad$ (Equation 1)}

The ligand has affinities for the two states governed by the dissociation equilibrium constant $K_{\mathrm{L}}$ and $K_{\mathrm{L}}{ }^{*}$ with

$$
\begin{aligned}
& K L=[R][L] /[\mathrm{LR}] \quad \text { (Equation 2) } \\
& K L^{*}=\left[R^{*}\right][L] /\left[\mathrm{LR}^{*}\right] \quad(\text { Equation } 3) \\
& \left.[R] \text { tot }=[R]+\left[R^{*}\right]+[\mathrm{LR}]+\left[\mathrm{LR}^{*}\right] \quad \text { (Equation } 4\right)
\end{aligned}
$$


The agonist has a higher affinity (lower dissociation equilibrium constant $\left[K_{\mathrm{L}}{ }^{*}\right]$ ) for $\mathrm{R}^{*}$ than for $\mathrm{R}\left(K_{\mathrm{L}} ; K_{\mathrm{L}} * / K_{\mathrm{L}} \ll 1\right)$ and thus displaces the equilibrium toward $\mathrm{R}^{*}$. A neutral antagonist has an identical affinity for $\mathrm{R}^{*}$ and $\mathrm{R}\left(K_{\mathrm{L}} * / K_{\mathrm{L}}=1\right)$, whereas an inverse agonist has a higher affinity for $\mathrm{R}$ than for $\mathrm{R}^{*}\left(K_{\mathrm{L}} * / K_{\mathrm{L}} \gg 1\right)$ and thus displaces the equilibrium toward $\mathrm{R}$.

With these equations, it is possible to derive the relationship between the concentration of receptors in the active form $\left[\mathrm{R}^{*}\right]+\left[\mathrm{LR}^{*}\right]$ and the concentration of agonist [L]. Expressing this as a fraction $\left(f_{\mathrm{R}^{*}}\right)$ of the total receptor concentration gives $\left(f R^{*}\right)=K L^{*}+[L] / K L^{*}(1+J)+\left(1+J K L^{*} / K L\right)[L]$ (Equation 5)

In COS-7 cells expressing 5- $\mathrm{HT}_{4}$ receptors, we observed no evidence for receptor reserve, even at high receptor density. Therefore, in this particular system, we can assume that cAMP production is proportional to $\left(f_{\mathrm{R}^{*}}\right)$ :

$\mathrm{cAMP}=K L^{*+}[L] / K L^{*}(1+J)+(1+J K L * / K L)[L] \quad$ (Equation 6)

It is important to note that the two-state model does not imply a linear relationship between $\mathrm{R}^{*}$ and response. From eq. $\underline{6}$ one can write: 1$)$ basal constitutive activity $=1 /(1+\mathrm{J})($ eq. 7$)$, taking [L] $=0$ in eq. $\underline{5}$; and 2) $V \max _{\max }=1 /\left(1+\mathrm{J}\left(K_{\mathrm{L}}{ }^{*} / K_{\mathrm{L}}\right)\right.$ (eq. 8), taking $\mathrm{L} \gg K_{\mathrm{L}}$ and $K_{\mathrm{L}}{ }^{*}$ in equation 5 .

For a full-potent agonist such as 5-HT, one can propose $K_{\mathrm{L}} * \ll K_{\mathrm{L}}$. Concerning 5-HT4 receptors, published experimental data indicate that the affinity of 5-HT for 5- $\mathrm{HT}_{4}$ receptors labeled with an agonist $\left(\left[{ }^{3} \mathrm{H}\right] 5-\mathrm{HT}\right)$ is equal to $6.3 \mathrm{nM}$ (Adham et al., 1996), whereas the affinity of 5-HT for 5-HT $\mathrm{H}_{4}$ receptors labeled with an antagonist $\left(\left[{ }^{3} \mathrm{H}\right] \mathrm{GR} 113808\right)$ is equal to 794 nM (Adham et al., 1996) These two affinities are likely to be close to the affinities of 5HT for $\mathrm{R}^{*}$ and $\mathrm{R}$, respectively, and thus probably close to $K_{\mathrm{L}}{ }^{*}$ and $K_{\mathrm{L}}$, respectively. Under these conditions, $\left[K_{\mathrm{L}}{ }^{*}\right] /\left[K_{\mathrm{L}}\right]=0.008$. It is more difficult to a priori approximate the $\mathrm{J}$ value. However, we know that even at physiological concentrations of 5- $\mathrm{HT}_{4}$ receptors, the basal constitutive activity is equal to 2 to 3 times the basal activity of mocked transfected cells (Claeysen et al., 1999, no. 1721). Therefore, we can make the minimal hypothesis that $10 \%$ of the receptors are under the $\mathrm{R}^{*}, \mathrm{~J}=9 . V_{\max }$ is then equal to $1 /(1+9 \times 0.008)=0.93$ (equation 5 with $\mathrm{J}=9$ and $K_{\mathrm{L}} * K_{\mathrm{L}}=0.008$ ), which is close to 1 .

When the four dose-effect curves of Fig. $\underline{5} \mathrm{~A}$ were plotted, taking for each curve the corresponding $V_{\max }$ for 5-HT equal to the upper limit of 1 , the curves were superimposable 
(Fig. 7A). In particular, the basal constitutive activities $(1 /(1+\mathrm{J}))(\mathrm{L}=0$ in equation 5$)$ were identical (Fig. 7 A). The value of $J$ can be calculated. $J$ was not statistically different when the receptor density varied from 200 to $8000 \mathrm{fmol} / \mathrm{mg}$ of protein (Fig. 7B). The mean value being equal to $6.15 \pm 0.62(n=12)$. This indicates that in these cells, $14 \pm 0.43 \%$ of receptors were in the $\mathrm{R}^{*}$ state in the absence of ligand. When a similar study was performed with mutated $5-\mathrm{HT}_{4} \mathrm{Rs}$, J values close to 1 were found for $5-\mathrm{HT}_{4} \mathrm{RA} 258 \mathrm{~L}$ and $5-\mathrm{HT}_{4} \mathrm{R} \Delta 327$, respectively (50\% of the receptors were in $\mathrm{R}^{*}$ in the absence of agonist; Fig. 7B). Again, the $\mathrm{J}$ values were constant regardless of the receptor density.

\section{DISCUSSION}

The 5-HT 4 receptor was first defined 10 years ago as being a receptor for which the classical 5-HT receptor antagonists were ineffective, except for tropisetron, which was a weak competitive antagonist (Dumuis et al., 1988). Several pharmaceutical companies have identified a large series of potent and specific agonists and antagonists (Bockaert et al., 1997). Therapeutic implications of 5- $\mathrm{HT}_{4}$ receptor ligands are now used in therapy, such as agonists in treatment of gastric hypomotility, improvement of esophageal acid reflux, and augmentation of stomach emptying (Bockaert et al., 1994; Eglen and Hedge, 1996). These companies also were interested in potential therapeutic indications of antagonists or partial agonists in pathologies such as irritable bowel syndrome, arrhythmia, and urinary incontinence (Eglen and Hedge, 1996; Bockaert et al., 1997; Gaster and King, 1997).

There is still some debate whether, under physiological conditions, the $\mathrm{J}$ constant and/or the density of receptors is high enough to trigger a detectable basal constitutive activity. As already indicated in the Introduction, metarhodopsin-II, the activated species of rhodopsin, decays to the apoprotein opsin and free all-trans-retinal. Opsin has an intrinsic activity that can be inhibited by reintroducing 11-cis-retinal (Surya et al., 1995). This constitutive activity could be the source of an adaptive signal that could switch itself off by converting this protein to rhodopsin. This may explain why photoreceptor sensitivity is related to transduction noise caused by previous light exposure. This suggestion was first made by Barlow (1964). If such events occur with 
other GPCRs systems under nonmutated conditions, it is evident that neutral, inverse agonist or partial agonist types of antagonists will not provide the same therapeutic effects. 5-HT $\mathrm{H}_{4} \mathrm{Rs}$ are good candidates for having physiological constitutive activity because in several cell lines, its expression at low density (100-500 fmol/mg) resulted in a 2- to 4-fold increase in basal constitutive activity (Claeysen et al., 1999). Therefore, the first goal of this study was to reconsider the pharmacological properties of drugs, which are 5- $\mathrm{HT}_{4} \mathrm{R}$ antagonists on $5-\mathrm{HT}_{4} \mathrm{R}$ expressed in mouse colliculi neurons, on a system expressing a basal constitutive activity. COS-7 cells expressing 100 to $8000 \mathrm{fmol} / \mathrm{mg}$ of protein of $5-\mathrm{HT}_{4} \mathrm{Rs}$ were chosen. A large series of neutral antagonists, all (except one) belonging to the benzodioxanyl ketone chemical class was found. Only two drugs were inverse agonists, both being indole derivatives (GR 125487 and SB 207266). All the others, belonging to various chemical classes, were partial agonists. Several compounds were particularly interesting. ML 10302 behaved as a neutral antagonist on 5- $\mathrm{HT}_{4} \mathrm{Rs}$ present in mouse colliculi neurons (Bockaert et al., 1997) but acted as a very active partial agonist in inducing contractions of guinea pig ileum and relaxation of rat esophagus (Langlois et al., 1994; Eglen and Hedge, 1996). In cells transfected with mouse or human $5-\mathrm{HT}_{4(\mathrm{a})}$ receptors as described herein, ML10302 acts as a very efficacious partial agonist. In the two-state model, the $V$ max activity of a partial agonist is equal to $V_{\max }=1 /\left(1+\mathrm{J} K_{\mathrm{L}} * / K_{\mathrm{L}} ;\right.$ eq. $\left.\underline{3}\right)$. Therefore, these results may suggest that either the $K_{\mathrm{L}} * / K_{\mathrm{L}}$ or the $\mathrm{J}$ constant are different when the mouse 5-HT4receptors are expressed in colliculi neurons or in transfected cells. It would be interesting to measure the $\mathrm{J}$ constant, as described herein, for a given receptor but on different cell lines. J may vary from one tissue to another depending on several factors (e.g., covalent modifications of $\mathrm{R}$ or $\mathrm{R}^{*}$, protein-lipid environment differentially affecting $\mathrm{R}$ or $\mathrm{R}^{*}$ ). Similarly, in rat esophagus and guinea pig ileum the $\mathrm{J}$ constant or the $K_{\mathrm{L}} / K_{\mathrm{L}}$ * ratio may be different. Blondel et al. (1998) described that ML10375, a potent and selective 5- $\mathrm{HT}_{4}$ receptor antagonist (Yang et al., 1997), behaved as an inverse agonist on human receptors transfected in COS-7 cells, the same model as we used herein. In contrast, we found that it behaved as a neutral antagonist. We have no explanation for such a discrepancy.

In classical pharmacological and operational models (Leff, 1988;Kenakin and Morgan, 1989), the response is described through a hyperbolic forcing function $E=$ 
$\mathrm{ET}[\mathrm{LR}] / \mathrm{Ct}+[\mathrm{LR}]$ (eq. 9), where [LR] is the concentration of the agonist (L) receptor complex, ET is the maximal response that could be obtained if [LR] is very high, compared with $\mathrm{C}_{\mathrm{t}}$, which represents the coupling constant (concentration of LR giving half of the ET response). In such a model, and at maximal agonist concentrations, the maximal response ( $E_{\max }=$ efficacy) is limited by the concentration of LR in the cell, equal to RT and the coupling constant $\mathrm{C}_{\mathrm{t}}$.

A partial agonist can be seen as a drug, giving an LR complex with a coupling constant higher than that of a full agonist. If $\mathrm{RT} \gg \mathrm{C}_{\mathrm{t}}$, increasing RT should provide a way of reaching the same $E$ max with both a partial and a full agonist. In contrast, if RT is low compared with $\mathrm{C}_{\mathrm{t}}\left([\mathrm{RT}] \ll \mathrm{C}_{\mathrm{t}}\right.$; absence of spare receptors) all the results found in this report are expected.

First, when [RT] was increased from $200 \mathrm{fmol} / \mathrm{mg}$ to $8300 \mathrm{fmol} / \mathrm{mg}$ the ratio between the full agonist 5-HT- and the partial agonist RS 23597-stimulated cAMP production was constant. This constant ratio also was observed in cells transfected with the mutated $5-\mathrm{HT}_{4}$ receptors.

Second, when [RT] was increased, the efficiencies of inverse agonists remained unchanged.

Third, we found a linear relationship between the increase in basal constitutive activity and the 5-HT-stimulated response, regardless of the wild-type and mutated receptor densities (up to $8000 \mathrm{pmol} / \mathrm{mg}$ of protein; Fig. 5). Such a constant stimulation of basal constitutive activity by $\beta 2$-adrenergic agonists also has been found by others in Chinese hamster ovary cells expressing increasing receptor concentrations (Samama et al., 1993; Ambrosio et al., 2000). In contrast, Chen et al. (2000) found that the stimulation of the human receptor-mediated constitutive activity, by the calcitonine hormone, decreased with increasing receptor density.

Fourth, the $\mathrm{EC}_{50}$ value of the 5-HT dose-response curves was unchanged when the density of receptor increased. This behavior also was found for $\beta_{2}$-adrenoreceptorstimulated cAMP production in Chinese hamster ovary cells (Ambrosio et al., 2000) and C6 glioma cells (Zhong et al., 1996). It is important to note that the number of transfected cells that remained the same regardless of the density of receptors $(60 \%)$ is probably because the total amount of DNA was kept constant during transfection. This was verified with epitope-tagged (c-Myc) 5-HT 4 receptors (data not shown). These 
data indicated that the response was not limited by the coupling components and especially the Gs protein and this conclusion was verified. The 5-HT stimulation of basal constitutive activity was not modified after overexpression of $\mathrm{G} \alpha_{\mathrm{sL}}$.

Fifth, the linearity between receptor occupancy and cAMP response also can be explained if one considers that 5-HT4 receptors are precoupled, i.e., associated with only one $G$ protein, at least for the $R^{*}$ form. Such a preferential association with a $G$ protein could be due to limited $\mathrm{R}$ diffusion within the membrane, $\mathrm{G}$ protein, and adenylyl cyclase. Although the precoupled hypothesis is old, it may apply to some receptors in particular cellular contexts (Braun and Levitsky, 1979; Lefkowitz et al., 1993; Kenakin, 1996). Recently, many precoupled GPCR/G proteins have been generated by fusing the coding sequences of both proteins (Seifert et al., 1999). No dramatic difference in the dose-response curves was observed compared with the natural system. For example, in a recent report, Walddoer et al. (1999) found the same $\mathrm{EC}_{50}$ in the cAMP dose-inhibition curves induced by $\mathrm{A}_{1}$-adenosine receptors or A1adenosine/Gai ${ }_{1}$-fused receptors. An important implication of these studies is that it not necessary for $\mathrm{G} \alpha$ to diffuse away from the receptor to reach its targets. The signaling proteins (receptors-G protein-effectors) are more likely to be packed together than previously thought.

Sixth, in a precoupled model, and providing that the G protein concentration is not limiting, which seems to be the case in this study (Fig. 6), increasing the receptor density will increase the maximal response but not the agonist potency. This is because the potency is an intrinsic property of each receptor related to the ratio $K_{\mathrm{L}} / K_{\mathrm{L}}$ * for a given drug. Such a precoupling hypothesis also can explain why the inhibition of the basal constitutive activity by the inverse agonist SB 207266 was constant regardless of the receptor density (Fig. 4). The efficacy of inverse agonists was dependent of the structure of the receptor, being lower for the mutated than for the wild-type receptor.

Seventh, only a few reports have tried to fit data obtained with GPCRs displaying constitutive activity to calculate important constants such as J. Samama et al. (1993) used the ternary complex model and found it to correctly fit their data. Bond et al. (1995) was successful in using the two-state model to fit the responses obtained with constitutive $\beta_{2}$-adrenergic receptors overexpressed in myocardial muscle of transgenic 
mice. However, in both studies, the data were fitted with a priori constant values with no attempt to obtain them from experimental data. One of the main assumptions required to fit the data with the two-state model, to calculate the J constant, without introducing to many a priori constants is that there is a linear relationship between the fraction of active receptors $\left(f_{R^{*}}\right)$ and the response. The data presented herein fulfill this assumption. $\mathrm{J}$ was $6.15 \pm 0.62$ when wild-type $5-\mathrm{HT}_{4}$ receptors are transfected in COS cells. This corresponds to $14 \pm 0.43 \%$ of the total wild-type $5-\mathrm{HT}_{4}$ receptor population, which is in the $\mathrm{R}^{*}$ state. We verified two important implications of the two-state model. First, the absence of effect of receptor density on the equilibrium $\mathrm{J}$ constant that determines the distribution of receptors between $\mathrm{R}$ and $\mathrm{R}^{*}$. Second, the absence of effect of receptor density on the efficacy of partial and inverse agonists. We also verified that the $\mathrm{J}$ constant was dependent on receptor structure, being close to $1\left(50 \%\right.$ of receptor under the $\mathrm{R}^{*}$ state) for mutated $5-\mathrm{HT}_{4} \mathrm{RA} 258 \mathrm{~L}$ and 5 $\mathrm{HT}_{4} \mathrm{R} \Delta 327$. However, it is likely that such a simple model may be less satisfactory to describe other GPCR systems in which a clear hyperbolic relationship exists between active receptors and the final response (Chen et al., 2000).

And eighth, when transfected in COS-7 cells, the relationships between the density of wild-type and mutated 5- $\mathrm{HT}_{4}$ receptors and the cAMP responses were linear. This allowed us to use the simple two-state model to describe the dose-effect curves and to determine the $\mathrm{J}$ constant, an important parameter in the allosteric hypothesis of receptor action.

\section{Acknowledgments}

We are grateful to J.-P. Pin, T. Galvez and ML. Parmentier for helpful comments and valuable discussions. Mrs. A.L. Turner-Madeuf and M. Passama are acknowledged for their help in language revision and preparation of figures respectively. 


\section{REFERENCES}

Adham N, Gerald C, Schechter L, Vaysse P, Weinshank R and Branchek T (1996) [3H]-5Hydroxytryptamine labels the agonist high affinity state of the cloned rat 5-HT4 receptor. Eur J Pharmacol 304:231-235.

Ambrosio C, Molinari P, Cotecchia S and Costa T (2000) Catechol-binding serines of beta(2)-adrenergic receptors control the equilibrium between active and inactive receptor states. Mol Pharmacol 57:198-210.

Ansanay H, Sebben M, Bockaert J and Dumuis A (1996) Pharmacological comparison between [3H]-GR113808 binding sites and functional 5-HT4 receptors in neurons. Eur J Pharmacol 298:165-174.

Barlow HB (1964) Dark-adaptation: A new hypothesis. Vision Res 4:47-58. Blondel O, Gastineau M, Langlois M and Fischmeister R (1998) The 5-HT4 receptor antagonist ML 10375 inhibits the constitutive activity of human 5-HT4c receptor. Br J Pharmacol 125:595-597.

Bockaert J, Ansanay H, Waeber C, Sebben M, Fagni L and Dumuis A (1994) 5-HT4 receptors. Potential therapeutic implications in neurology and psychiatry. Cent Nerv Syst Drugs 1:6-15.

Bockaert J, Fagni L and Dumuis A (1997) 5-HT4 Receptors: An update, in Handbook of Experimental Pharmacology: Serotoninergic Neurons and 5-HT Receptors in the CNS (Baumgarten HG and Go“thert M eds) pp 439-465, Springer Verlag, Berlin.

Bond RA, Leff P, Johnson TD, Milano CR, Rockman HA, McMinn TR, Apparsundaran S, Hyek MF, Kenakin TP, Allen LF and Lefkowitz RJ (1995) Physiological effects of inverse agonists in transgenic mice with myocardial overexpression of b2-adrenoceptor. Nature (Lond) 374:272-276.

Bradford MM (1976) A rapid and sensitive method for the quantitation of microgram quantities of protein utilising the principle of protein-dye binding. Anal Biochem $72: 248-254$.

Braun S and Levitsky A (1979) Adenosine receptor permanently coupled to turkey erythrocyte adenylate cyclase. Biochemistry 18:2134-2138.

Chen G, Way J, Armour S, Watson C, Queen K, Jayawickreme CK, Chen WJ and Kenakin T (2000) Use of constitutive $\mathrm{G}$ protein-coupled receptor activity for drug discovery. Mol Pharmacol 57:125-134

Chidiac P, Hebert TE, Valiquette M, Dennis M and Bouvier M (1994) Inverse agonist activity of b-adrenergic antagonists. Mol Pharmacol 45:490-499.

Claeysen S, Faye P, Sebben M, Lemaire S, Bockaert J and Dumuis A (1997) Cloning and expression of human 5-HT4S receptors. Effect of receptor density on their coupling to adenylyl cyclase. Neuroreport 8:3189-3196. 
Claeysen S, Sebben M, Becamel C, Bockaert J and Dumuis A (1999) Novel brainspecific 5HT4 receptor splice variants show marked constitutive activity: Role of the C-terminal intracellular domain. Mol Pharmacol 55:910-920.

Claeysen S, Sebben M, Journot L, Bockaert J and Dumuis A (1996) Cloning, expression and pharmacology of the mouse 5-HT4L receptor. FEBS Lett 398:19-25.

Clark RD (1998) Medicinal chemistry of 5-HT4 receptor ligands, in 5-HT4 Receptors in the Brain and Periphery (Eglen RM ed) pp 1-48, Springer Verlag, Berlin. Colquhoun D (1973) The relation between classical and cooperative models for drug action, in Drug Receptors (Rang HP ed) pp 149-174, University Park Press, Baltimore.

Costa T, Ogino Y, Munson PJ, Onaran HO and Rodbard D (1992) Drug efficacy at guanine nucleotide-binding regulatory protein-linked receptors; thermodynamic interpretation of negative antagonism and of receptor activity in the absence of ligand. Mol Pharmacol 41:549-560.

Dumuis A, Bouhelal R, Sebben M, Cory R and Bockaert J (1988) A non classical 5hydroxytryptamine receptor positively coupled with adenylate cyclase in the central nervous system. Mol Pharmacol 34:880-887.

Eglen RM and Hedge SS (1996) 5-hydroxytryptamine (5-HT)4 receptors: Physiology, pharmacology and therapeutic potential. Exp Opin Invest Drugs 5:373-388.

Gaster L and King FD (1997) Serotonin 5-HT3 and 5-HT4 receptor antagonists. Med Res Rev 17:163-214. Karlin A (1967) On the application of "a plausible model" of allosteric proteins to the receptor for acetylcholine. J Theor Biol 16:306-320.

Kenakin T (1996) The classification of seven transmembrane receptors in recombinant expression systems. Pharmacol Rev 48:413-463.

Kenakin TP and Morgan PH (1989) Theoretical effects of single and multiple transducer receptor coupling proteins on estimates of the relative potency of agonists. Mol Pharmacol 1:445-451.

Kjelsberg MA, Cotecchia S, Ostrowski J, Caron MC and Lefkowitz RJ (1992) Constitutive activation of the a1B-adrenergic receptor by all amino acid substitutions at a single site. J Biol Chem 267:1430-1433.

Langlois M, Zhang L, Yang D, Bre' mont B, Shen S, Manara L and Croci T (1994) Design of a potent 5-HT4 receptor agonist with nanomolar affinity. Bioorg Med Chem Lett 4:1433-1436.

Leff P (1988) Analysis of the agonist action using the operational model. Trends Pharmacol Sci 9:935-937.

Leff P (1995) The two-state model of receptor activation. Trends Pharmacol Sci 16:89-97.

Lefkowitz RJ, Cotecchia S, Samana P and Costa T (1993) Constitutive activity of receptors coupled to guanine nucleotide regulatory proteins.

Trends Pharmacol Sci 14:303-304. Monod J, Wyman J and Changeux J-P (1965) On the nature of allosteric transitions: A plausible model. J Mol Biol 12:88-118. 
Samama P, Cotecchia S, Costa T and Lefkowitz RJ (1993) A mutation-induced activated state of the b2-adrenergic receptor. Extending the ternary complex model. J Biol Chem 268:4625-4635.

Seifert R, Wenzel-Seifert K and Kobilka BK (1999) GPCR-Galpha fusion proteins: Molecular analysis of receptor-G-protein coupling. Trends Pharmacol Sci 20:383-389.

Surya A, Foster KW and Know BE (1995) Transducin activation by bovine opsin apoprotein. J Biol Chem 270:5024-5031.

Thron CD (1970) Graphical and weighted regression anlyses for the determination of agonist dissociation constants. J Pharmacol Exp Ther 175:541-553.

Waldhoer M, Wise A, Milligan G, Freissmuth M and Nanoff C (1999) Kinetics of ternary complex formation with fusion proteins composed of the $\mathrm{A}(1)$-adenosine receptor and G protein alpha-subunits. J Biol Chem 274:30571-30579.

Yang D, Soulier JL, Sicsic S, Mathe-Allainmat M, Bremont B, Croci T, Cardamone R, Aureggi G and Langlois M (1997) New esters of 4-amino-5-chloro-2- methoxybenzoic acid as potent agonists and antagonists for 5-HT4 receptors. J Med Chem 40:608-621.

Zhong H, Guerrero SW, Esbenshade TA and Minneman KP (1996) Inducible expression of B1- and B2-adrenergic receptors in rat C6 glioma cells: Functional interactions between closely related subtypes. Mol Pharmacol 50:175-184. 


\section{LEGENDS TO FIGURES}

\section{Figure 1}

Effects of a series of 5- $\mathrm{HT}_{4}$ receptor antagonists on agonist-independent cAMP production in COS-7 cells expressing transiently either $\mathrm{h} 5-\mathrm{HT}_{4(\mathrm{a})}$ or $\mathrm{m} 5-\mathrm{HT}_{4(\mathrm{a})}$ receptors. The effect of 24 ligands at saturating concentration $(10 \mu \mathrm{M})$ was evaluated on $\mathrm{h} 5-\mathrm{HT}_{4(\mathrm{a})}$ and $\mathrm{m} 5-\mathrm{HT}_{4(\mathrm{a})}$ transiently transfected in COS-7 cells expressing $1530 \pm 156$ and $1860 \pm 175 \mathrm{fmol} / \mathrm{mg}$ of protein, respectively. The percentage conversion of $\left[{ }^{3} \mathrm{H}\right] \mathrm{ATP}$ to $\left[{ }^{3} \mathrm{H}\right] \mathrm{cAMP}$ in mocktransfected COS-7 cells was $0.157 \pm 0.013$. cAMP production was measured for $15 \mathrm{~min}$ and expressed as a percentage of control. Each experimental measurement was performed in triplicate. The data show the mean \pm S.E. of four separate experiments. The classical $5-\mathrm{HT}_{4}$ receptor antagonists are classified in $\mathrm{A}$ and $\mathrm{D}$ with few effects on the basal levels and defined as neutral antagonists. In $\mathrm{B}$ and $\mathrm{E}, 5-\mathrm{HT}_{4}$ receptor antagonists that stimulated cAMP formation, defined as partial agonists, were compared with 5-HT. In C and F, 5-HT4receptor antagonists that inhibited agonist-independent cAMP production are classified as inverse agonists.

\section{Figure 2}

Concentration-response curves of five 5-HT4 receptor antagonists on agonist-independent and -dependent cAMP production in COS-7 cells transiently expressing m5-HT4(a) receptors. COS-7 cells transiently expressing $1650 \pm 145 \mathrm{fmol} / \mathrm{mg}$ of protein of m5-HT4(a) receptors were exposed to increasing concentrations of each drug in the absence (A) and in the presence (B) of $0.1 \mu \mathrm{M} 5-\mathrm{HT}$. cAMP production measured for $15 \mathrm{~min}$ was expressed as a percentage of maximal 5-HT response. The results are representative of three experiments performed in triplicate.

\section{Figure 3}

Concentration-response curves of two potent and selective inverse agonists (GR 125487 and SB 207266) on agonist-independent and -dependent cAMP production on COS-7 cells transiently expressing $\mathrm{m} 5-\mathrm{HT}_{4(\mathrm{a})}$ receptors. COS-7 cells transiently expressing $1520 \pm 128$ $\mathrm{fmol} / \mathrm{mg}$ of protein of ${\mathrm{m} 5-\mathrm{HT}_{4} \text { (a) }}$ receptors were exposed to increasing concentrations of each drug in the absence (A) and in the presence (B) of $0.1 \mu \mathrm{M}$ 5-HT. cAMP production was measured for $15 \mathrm{~min}$ and expressed as a percentage of basal cAMP formation (A) and as a percentage of maximal 5-HT response (B). The results are representative of three independent experiments performed in triplicate. 


\section{Figure 4}

Efficiencies of a partial agonist (RS 23597) and an inverse agonist (SB 207266) on constitutively active wild-type and mutated $5-\mathrm{HT}_{4}$ receptors. Effect of receptor density. A, COS-7 cells expressing five different receptor densities (from 200 to $8300 \mathrm{fmol} / \mathrm{mg}$ of protein) were assayed for basal, RS $23597(10 \mu \mathrm{M})$-, and 5-HT $(10 \mu \mathrm{M})$-stimulated cAMP production. Levels of cAMP accumulation were measured after a 15-min incubation and expressed as a percentage of cAMP accumulation in mock-transfected cells. The percentage conversion of $\left[{ }^{3} \mathrm{H}\right]$ ATP to $\left[{ }^{3} \mathrm{H}\right]$ cAMP in mock-transfected COS-7 cells was $0.115 \pm 0.014$. Each value is the mean \pm S.E. of four independent experiments each performed in triplicate. B, efficacy of the inverse agonist (SB 207266) on basal constitutive activities of m5-HT 4 (a) receptors expressed at different receptor densities (from 100 to $6000 \mathrm{fmol} / \mathrm{mg}$ of protein). Basal and residual cAMP productions in the presence of SB $207266(100 \mathrm{nM})$ were measured after a 15-min incubation and expressed as a percentage of cAMP accumulation in mocktransfected cells. The percentage conversion of $\left[{ }^{3} \mathrm{H}\right] \mathrm{ATP}$ to $\left[{ }^{3} \mathrm{H}\right] \mathrm{cAMP}$ in mock-transfected COS-7 cells was $0.134 \pm 0.018$. Each value is the mean \pm S.E. of four independent experiments each performed in triplicate. C, cAMP accumulations in response to RS 23597 reported in A were expressed as a percentage of maximal 5-HT response and plotted as a function of $\mathrm{m}^{-} \mathrm{HT}_{4(\mathrm{a})}$ receptor density. $\mathrm{D}$, residual cAMP productions in the presence of SB $207266(100 \mathrm{nM})$ reported in B were expressed as a percentage of basal cAMP formation and plotted as a function of $\mathrm{m} 5-\mathrm{HT}_{4(\mathrm{a})}$ receptor density. E, cAMP accumulations in response to RS $23597(10 \mu \mathrm{M})$ on COS-7 cells transiently expressing two highly constitutive mutated 5$\mathrm{HT}_{4}$ receptors: $\mathrm{m} 5-\mathrm{HT}_{4} \Delta 327$ and $\mathrm{m} 5-\mathrm{HT}_{4(\mathrm{a})} \mathrm{A} 258 \mathrm{~L}$ receptors were directly expressed as a percentage of maximal 5-HT response and plotted as a function of receptor densities. F, efficacy of the inverse agonist (SB 207266) on basal constitutive activities on COS-7 cells transiently expressing $\mathrm{m} 5-\mathrm{HT}_{4} \Delta 327$ and $\mathrm{m} 5-\mathrm{HT}_{4(\mathrm{a}) \mathrm{A}} \mathrm{A} 58 \mathrm{~L}$ receptors. Residual cAMP productions in the presence of SB $207266(100 \mathrm{nM})$ were expressed as a percentage of basal cAMP formation and plotted as a function of $\mathrm{m} 5-\mathrm{HT}_{4} \Delta 327$ and $\mathrm{m} 5-\mathrm{HT}_{4(\mathrm{a})} \mathrm{A} 258 \mathrm{~L}$ receptor densities.

\section{Figure 5}

Effect of receptor densities on the efficacy and potency of a full agonist (5-HT) on constitutively active wild-type and mutated 5- $\mathrm{HT}_{4}$ receptors. A, cAMP accumulation in response to increasing concentrations of 5-HT measured in COS-7 cells expressing different

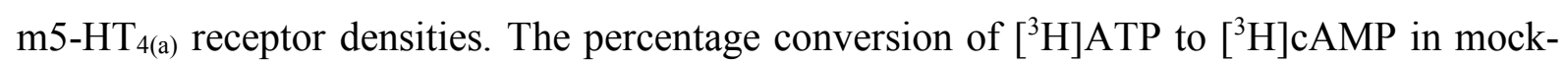
transfected COS-7 cells was $0.123 \pm 0.014$. cAMP production were measured for $15 \mathrm{~min}$ and 
expressed as a percentage of control. Each experimental measurement was performed in triplicate. The data shown are the mean \pm S.E. of three separate experiments. B, maximal cAMP accumulations in response to 5-HT reported in A were expressed as a percentage of basal cAMP production and plotted as a function of $\mathrm{m} 5-\mathrm{HT}_{4(\mathrm{a})}$ receptor density. $\mathrm{C}$, another representation of cAMP production performed in A. In this representation, cAMP productions were expressed in response to increasing concentrations of 5-HT as a fraction of maximal 5-HT response (taken as equal to 100 in each condition). D, maximal cAMP accumulations in response to 5-HT measured in COS-7 cells expressing different highly constitutive mutated $\mathrm{m} 5-\mathrm{HT}_{4} \Delta 327$ and $\mathrm{m} 5-\mathrm{HT}_{4(\mathrm{a})} \mathrm{A} 258 \mathrm{~L}$ receptors densities were expressed as a percentage of basal production and plotted as a function of receptor densities.

\section{Figure 6}

Effect of overexpression of $\mathrm{G} \alpha_{\mathrm{sL}}$ on 5-HT stimulated cAMP production in function of m5-HT4(a)receptor densities. Maximal cAMP accumulations in response to 5-HT measured in COS-7 cells expressing different concentrations of $\mathrm{m}^{5}-\mathrm{HT}_{4(\mathrm{a})}$ receptors in the absence or presence of overexpression of $\mathrm{G} \alpha_{\mathrm{SL}}$ expressed as a percentage of basal

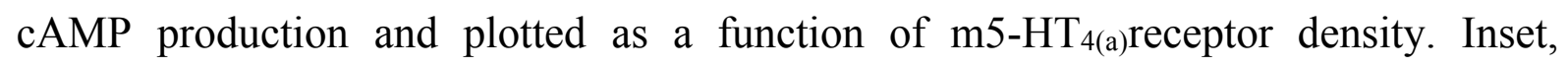
immunoblotting of endogenous $\mathrm{G} \alpha_{\mathrm{s}}$ expressed in COS-7 cells (line 1) and the immunoblotting of endogenous $\mathrm{G} \alpha_{\mathrm{s}}$ plus $\mathrm{G} \alpha_{\mathrm{sL}}$ overexpressed in COS-7 cells (line 2).

\section{Figure 7}

Calculation of the allosteric $\mathrm{J}$ constant. A, according to the two state-model, basal values are equal to $1 /(1+\mathrm{J})$ (eq. 7). cAMP productions in response to increasing concentration of 5-HT performed in Fig. 4 A were expressed as a fraction of maximal 5-HT response (taken as equal to 1 in each condition). B, J constant values calculated from basal values equal to $1 /(1+\mathrm{J})$ (eq. 7 ) are plotted at increasing receptor densities for the wild-type $\mathrm{m} 5-\mathrm{HT}_{4(\mathrm{a})}$ and both mutated $\mathrm{m} 5-\mathrm{HT}_{4} \Delta 327$ and $\mathrm{m} 5-\mathrm{HT}_{4(\mathrm{a})} \mathrm{A} 258 \mathrm{~L}$ receptors. 

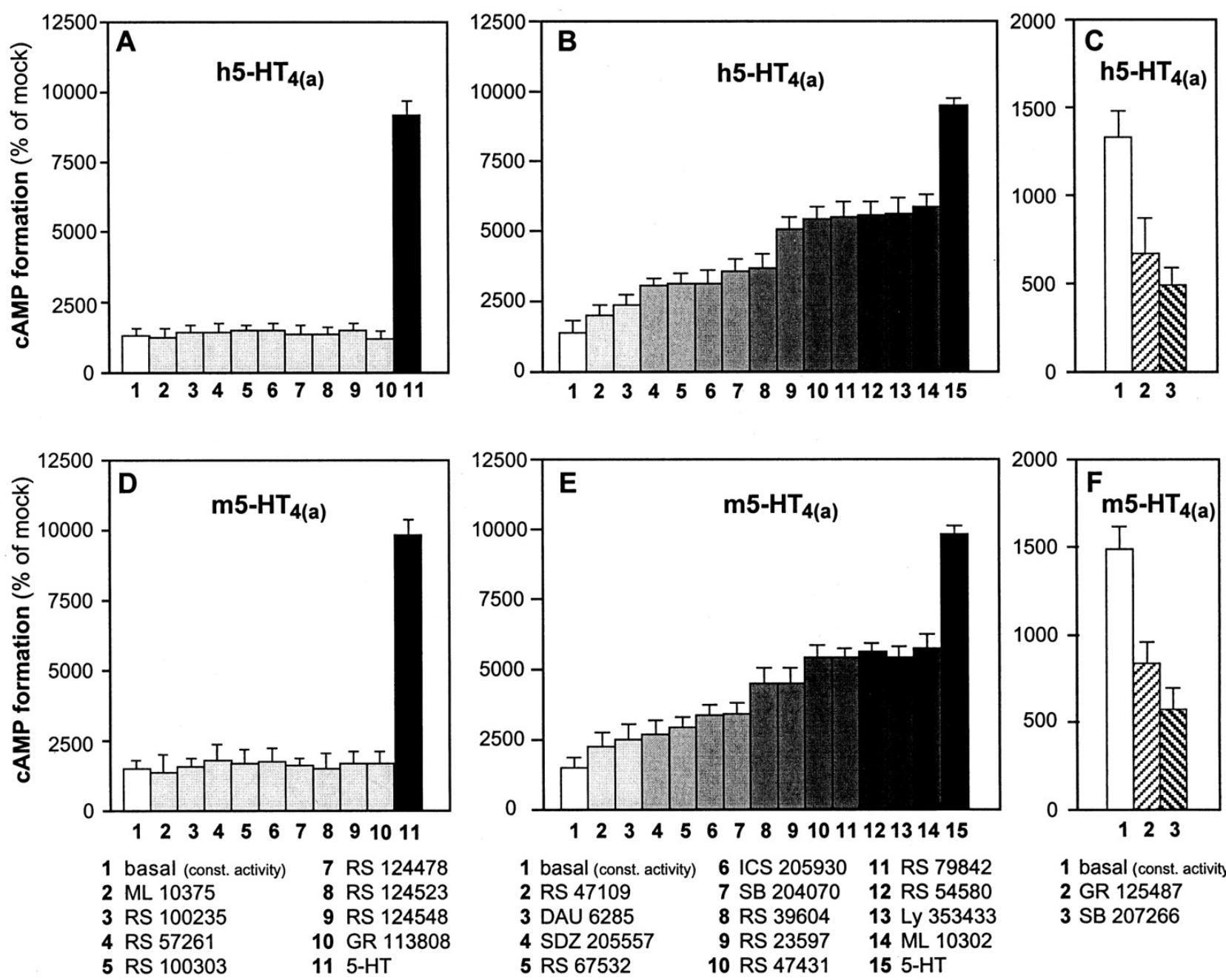

1 basal (const. activity) 6 ICS 20593011 RS 79842

2 RS $47109 \quad 7$ SB $204070 \quad 12$ RS 54580

3 DAU $6285 \quad 8$ RS $39604 \quad 13$ Ly 353433

4 SDZ 205557

basal (const activity)

2 GR 125487

3 SB 207266

5 RS 100303

5 RS 67532

9 RS 23597
10 RS 47431

15 5- HT

Figure 1 

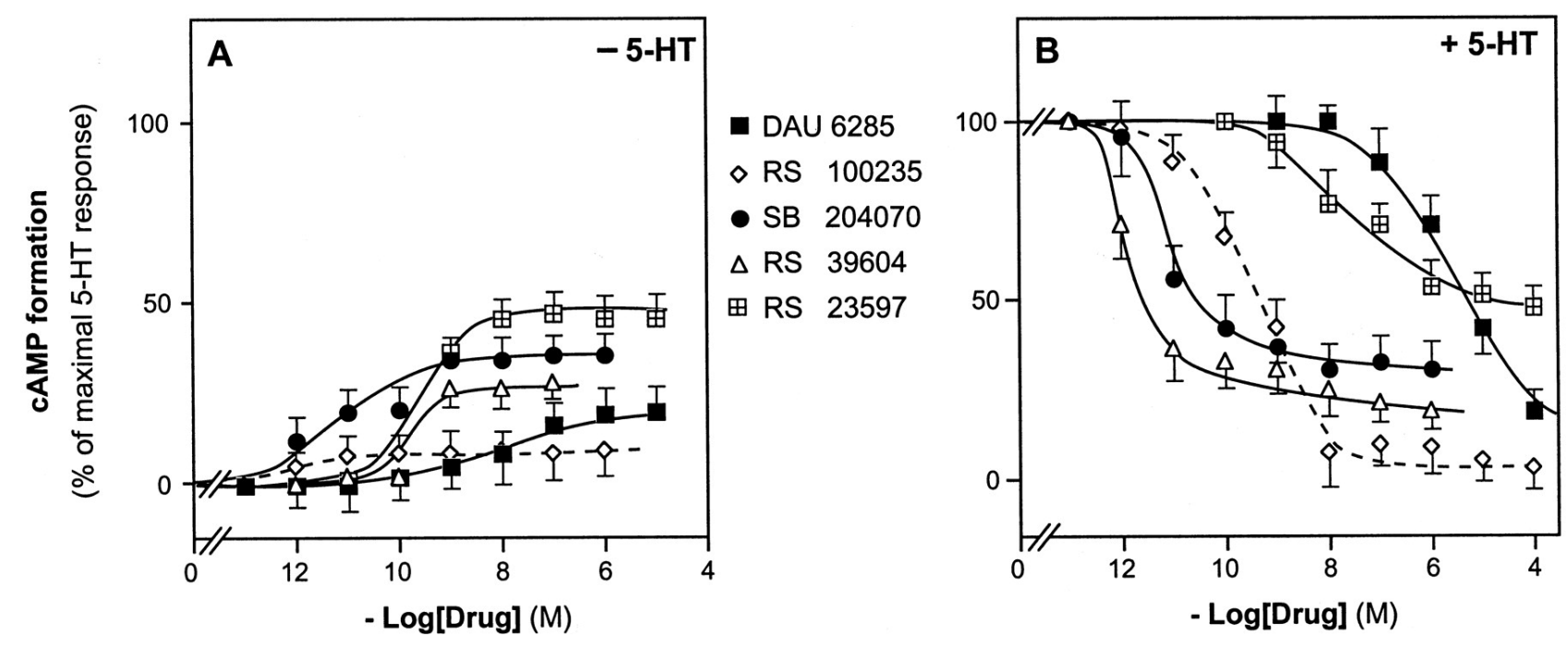

Figure 2 

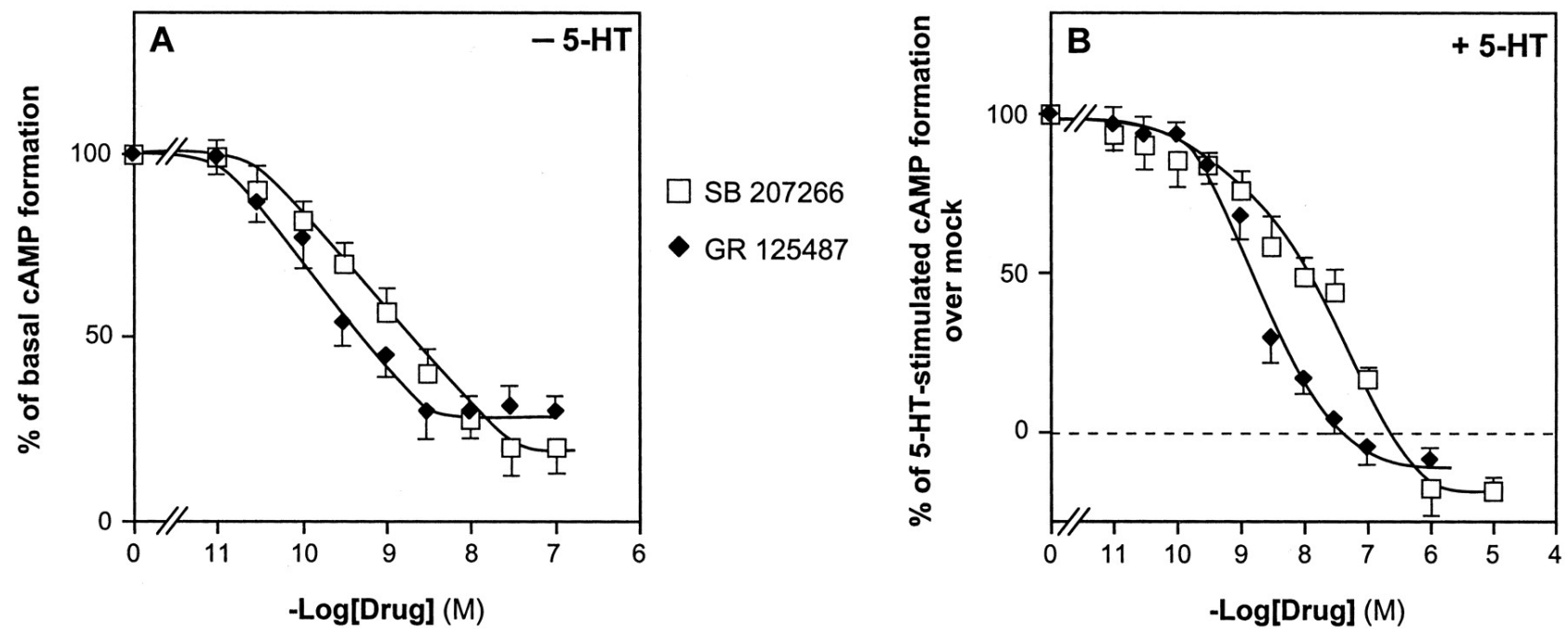

Figure 3 

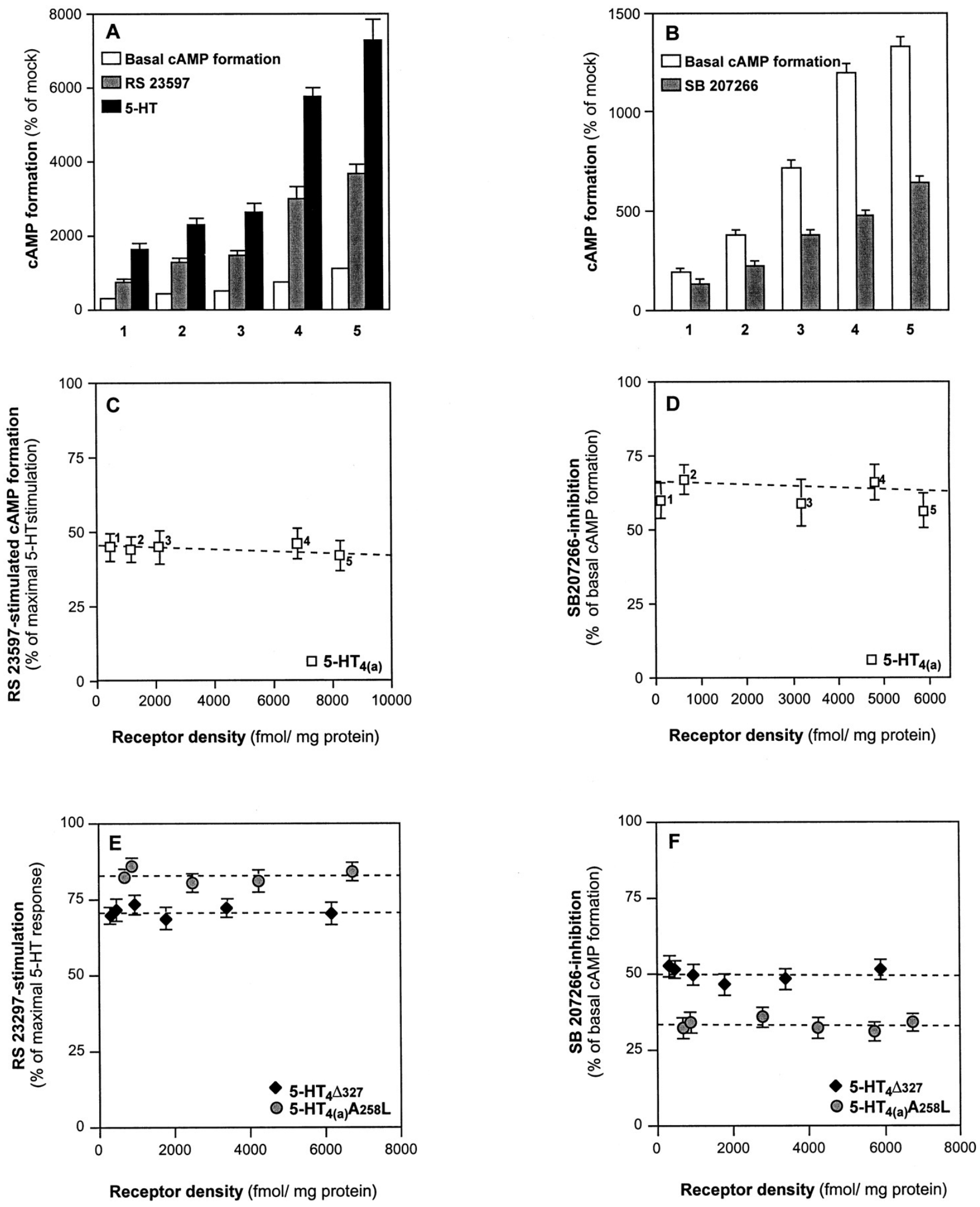

Figure 4 

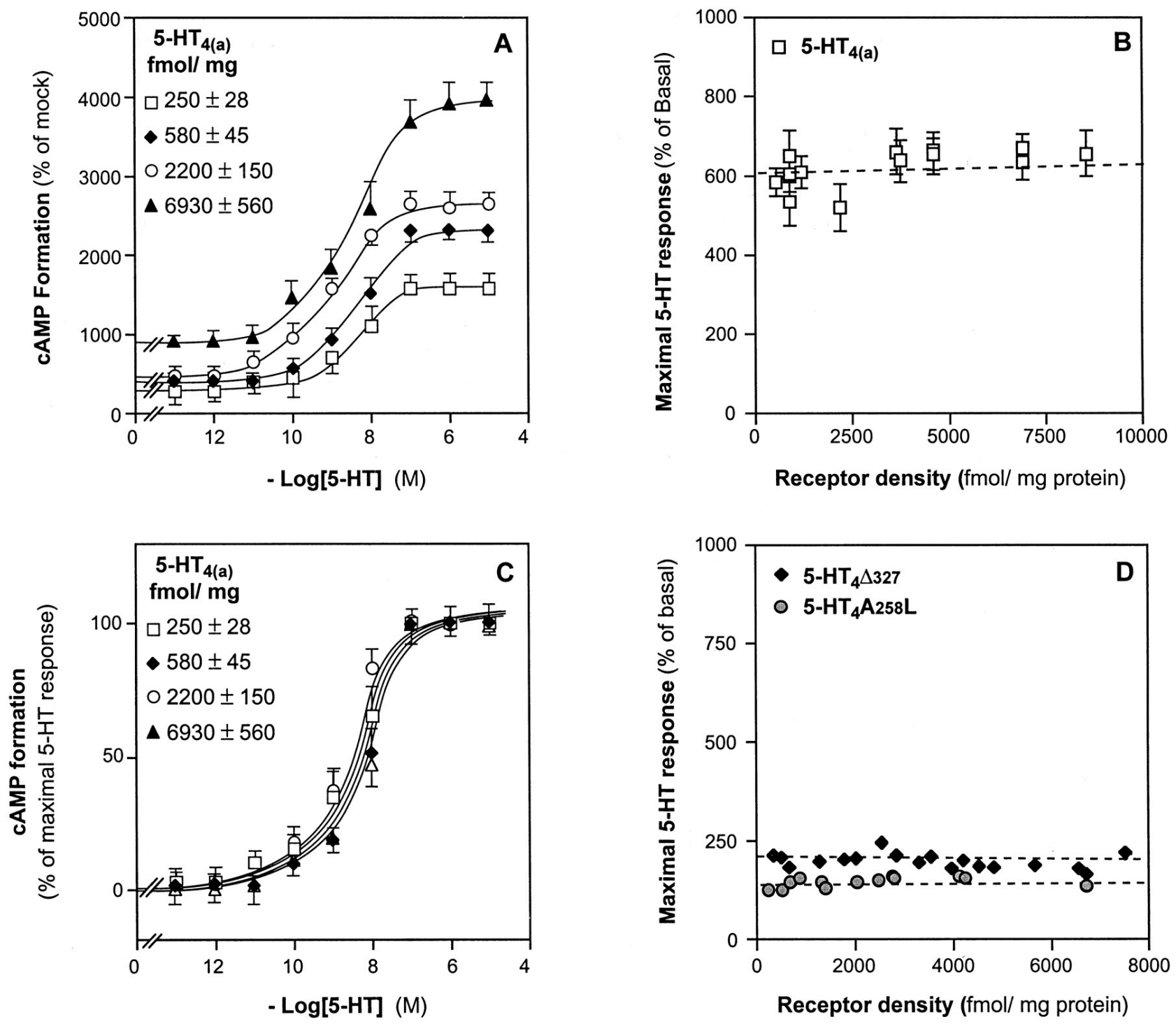

Figure 5 


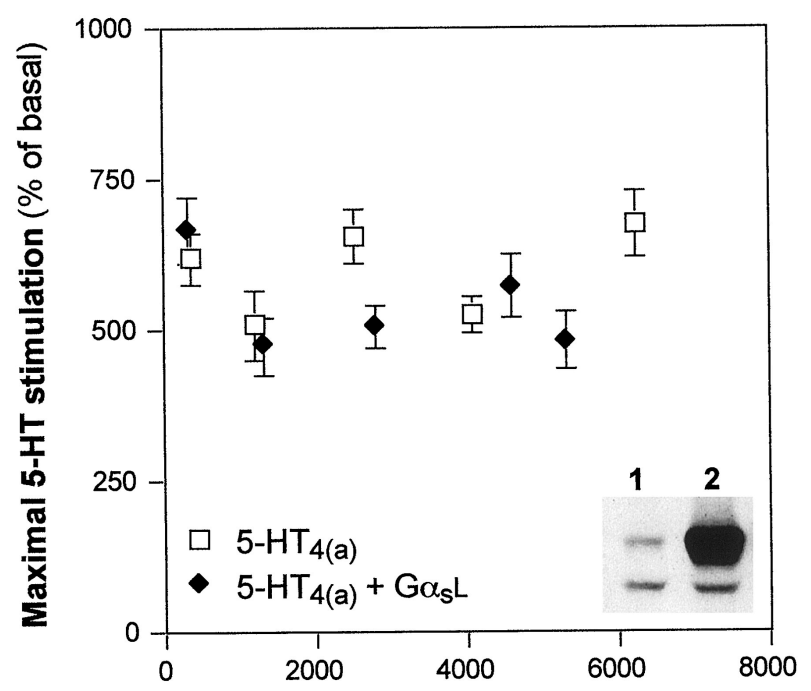

Receptor density (fmol/ mg protein)

Figure 6 

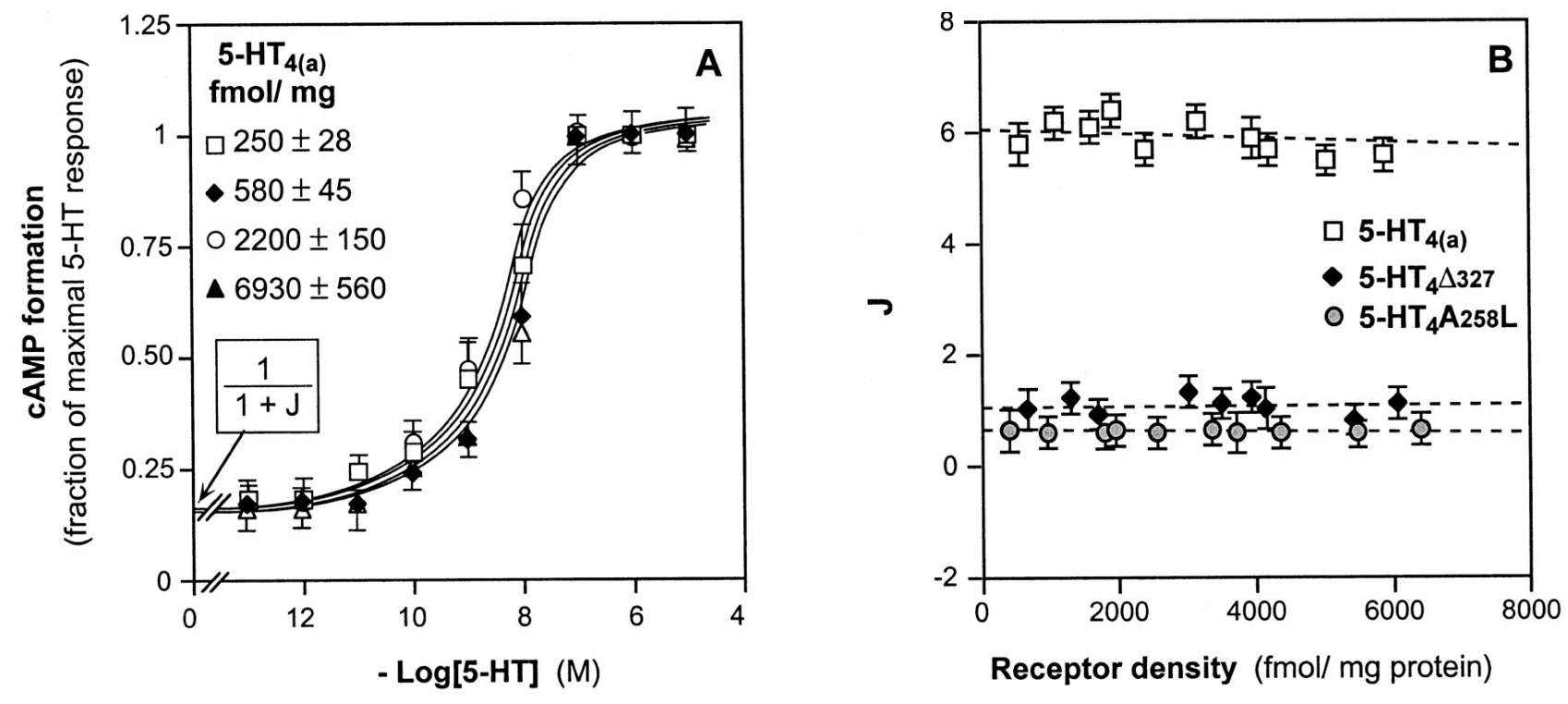

Figure 7 


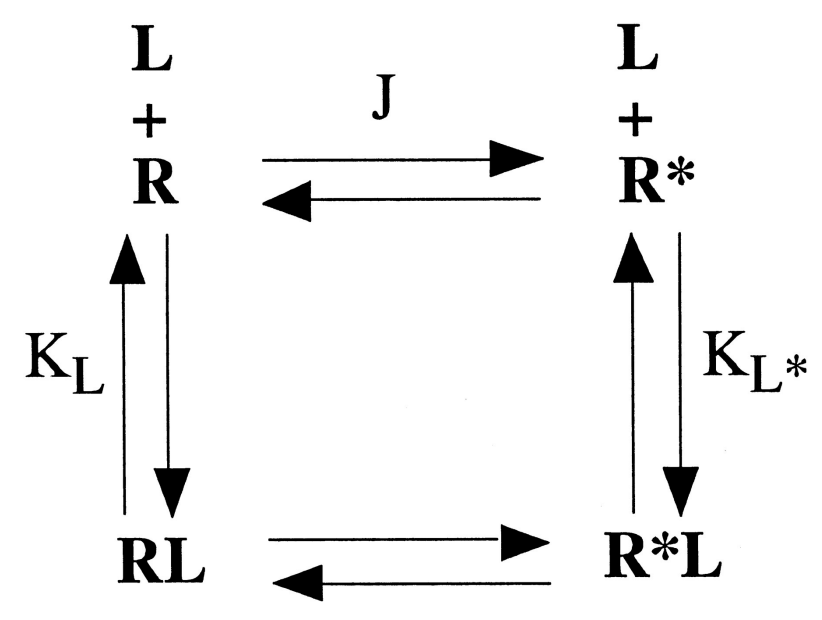

Scheme 1 